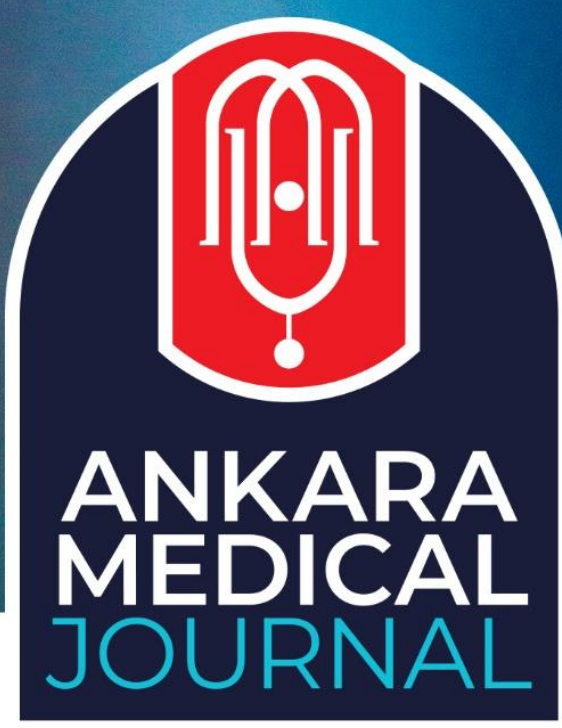

Research Article

Ankara Med J, 2020;(4):814-824 // 10 10.5505/amj.2020.79095

\title{
RELATIONSHIP BETWEEN THE ANXIETY AND DEPRESSION LEVELS OF CHILDREN WITH TYPE 1 DIABETES AND THE RESILIENCE AND COPING ATTITUDES OF THEIR PARENTS
}

\section{TIPP 1 DIYYABETLİ ÇOCUKLARIN KAYGI VE DEPRESYON DÜZEYLERİ İLE EBEVEYNLERINIIN YILMAZLIK VE BAŞA ÇIKMA TUTUMLARI ARASINDAKİ İLIŞKİ}

(D) Özlem Kara1, (D) Mehmet Erdem Uzun²

1 University of Health Sciences Bursa Yüksek İhtisas Training and Research Hospital, Department of Pediatric Endocrinology, Bursa

${ }^{2}$ University of Health Sciences Bursa Yüksek İhtisas Training and Research Hospital, Department of Pediatric and Adolescent Psychiatry, Bursa

Yazışma Adresi / Correspondence:

Özlem Kara (e-mail: dr.ozlemkara@hotmail.com)

Geliş Tarihi (Submitted): 07.06.2020 // Kabul Tarihi (Accepted): 26.10.2020

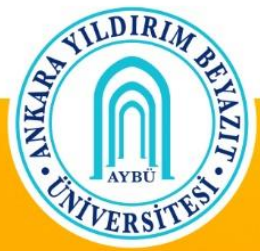

Ankara Yildırım Beyazıt University Faculty of Medicine Department of Family Medicine 


\title{
Öz
}

Amaç: Bu çalışma ile T1DM'li çocukların kaygı ve depresyon durumunu belirleyerek, bu durumun ebeveynlerin başa çıkma tutumları ve yılmazlık düzeyleri ile olan ilişkisini ve glisemik kontrol üzerine olan etkilerini saptamayı amaçladık.

Materyal ve Metot: Çalıșmamıza toplam 71 hasta ve bu hastaların ebeveynleri alınmıştır. Çocuklara, Çocuk Depresyon Ölçeği (ÇDÖ) ve Çocuklar İçin Anksiyete Tarama Ölçeği (ÇATÖ), ebeveynlerine Başa Çıkma Tutumlarını Değerlendirme Ölçeği (BÇTDÖ) ve Aile Yılmazlık Ölçeği (AYÖ) uygulanmıștır. Tüm katılımcılara kişisel bilgi formu doldurulmuștur. Hastaların glisemik kontrol düzeyleri son bir yıldaki ortalama glikolize hemoglobin (HbA1c) düzeylerine göre değerlendirilmiştir.

Bulgular: Annenin yılmazlık düzeyi arttıkça çocuğun depresyon durumunun azaldığı görülmüştür. Anne ve babada en fazla sorun odaklı başa çıkma tutumu olduğu gözlendi. Başa çıkma tutumlarının alt ölçekleri değerlendirildiğinde; diyabet süresi ile annenin 'zihinsel boş verme', babanın ise 'aktif baş etme', 'plan yapma' ve 'sosyal destek kullanımı' arasında negatif iliş̧i saptanmıştır. Yine annenin başa çıkma tutumu alt ölçeğinden 'şakaya vurma' ile çocuğun depresyon durumu arasında ve 'aktif baş etme' ile çocuğun anksiyete düzeyi arasında pozitif ilişki saptandl.

Sonuç: Kronik hastalığa sahip çocukları olan ebeveynler farklı başa çıkma tutumları sergilemektedirler. Bu tutumlar çocuk üzerinde değişik etkilere neden olmaktadır. Sonuçta ailelerin uygun baş etme stratejilerini kullanmaları çocukları üzerinde olumlu etki yaratacaktır. Bu konuda aileleri yönlendirmek önem arz etmektedir.

Anahtar Kelimeler: Çocuk, tip 1 diabetes mellitus, yılmazlık, başa çıkma tutumları, ebeveyn.

\begin{abstract}
Objectives: With this study, we aimed to identify the anxiety and depression status of children with T1DM and to determine its relationship with parents' coping attitudes and resilience levels and the effects on glycaemic control.

Materials and Methods: Our study included seventy-one patients of T1DM and their parents. We applied the Children's Depression Inventory (CDI) and the Screen for Child Anxiety Related Disorders (SCARED) to the children, and the COPE Inventory and the Family Resilience Scale (FRS) to the parents. All participants filled out the personal information form was filled out. The patients' glycaemic control levels were assessed based on the average glycosylated hemoglobin (HbA1c) levels of the previous year.

Results: The child's depression status decreased as the mother's resilience increased. In the mothers and fathers, the most frequently observed problem was problem-focused coping attitudes. When we evaluated the subscales of the coping attitudes, a negative statistically significant correlation was determined between the duration of diabetes and the mother's "mental disengagement," and the father's "active coping," "planning," and "using social support." Again, a positive statistically significant correlation was identified between the mother's "humor" coping attitude subscale and the child's depression status, and between "active coping" and the child's anxiety level.

Conclusion: Parents with children who have a chronic disease exhibit different coping attitudes. These attitudes cause various effects on the child. In conclusion, families using appropriate coping strategies will have a positive impact on their children. It is essential to guide families in this respect.

Keywords: Children, type 1 diabetes mellitus, resilience, coping strategies, parent.
\end{abstract}




\section{Introduction}

Type 1 Diabetes Mellitus (T1DM), one of the most common chronic diseases in childhood, is caused by insulin deficiency following the destruction of the insulin-producing pancreatic beta cells. It most commonly presents in childhood. Until the early 2000s, the incidence of childhood T1DM was reported to be rising worldwide, with reported increases of 2 to 5 percent per year in Europe, the Middle East, and Australia. ${ }^{1}$

Disease management is critical in T1DM. Balanced nutrition requires carbohydrate counting, multiple insulin doses, physical activity, regular blood glucose measurement, and measurement of ketones in urine when necessary. ${ }^{2}$ By doing so, reasonable glycemic control can be achieved. However, having a child with T1DM, a disease with rather complicated management causes many stresses that render parents to use different coping strategies. $^{3}$ The conditions of a chronic illness lead to stress, not only in parents but also in children. Although chronic diseases are an important stress factor in a child's life, they do not always cause psychiatric problems. In the presence of protective factors, the effect of stress decreases and mostly results in increasing mental resilience. ${ }^{4}$ Since there is a lot of evidence about the benefits of effective coping methods, the coping strategies developed by parents will particularly have some effects on children. In other words, the coping approach that each individual chooses plays a vital role in physical and mental health and provides successful stress management.3 When proper coping methods are not used, parents and children fail to establish real communication and tend to deal with the experienced event on their own in a non-functional way.

The attitudes of coping with stress have been studied in many chronic diseases, but the number of studies mainly focusing on parents of children with T1DM is limited. Furthermore, although it has been determined in studies conducted that parents' coping attitudes are related to psychological distress, their effects on the child have not been examined before.

Resilience is the individual's positive adaptation, development, and survival despite being exposed to situations and experiences that have negative consequences. ${ }^{5}$ In particular, the level of resilience, which is a potential factor in diabetes management, is likely to affect family health positively. ${ }^{6}$ In many studies conducted, the resilience levels of patients have important effects on glycemic control.,8 The studies conducted have focused on adult diabetics. No studies evaluate the resilience levels of parents of a child with T1DM, their child's glycemic control level, and the psychological distress status.

This study aimed to determine the relationship between coping attitudes and the resilience levels in the parents of a child with T1DM, the child's anxiety and depression, and the effects on glycemic control. 


\section{Materials and Methods}

\section{Study group}

Patients diagnosed with T1DM and followed-up by the pediatric endocrinology department of a tertiary hospital and their parents were included in the single-center and cross-sectional study. The study protocol was approved by the Institutional clinical research ethics committee (2011-KAEK-25 2019/03-14) under the Declaration of Helsinki principles. Written informed consent to participate in this study was obtained from the children and/or parents or legal tutors of the children after explaining the nature and possible consequences of the study. Written and verbal consents were obtained from the children and parents included in the study. The study inclusion criteria were being ten years of age or older, speaking and understanding Turkish, and having been followed-up with the diagnosis of diabetes for at least one year. All patients with T1DM were administered intensive insulin therapy (basal-bolus).

\section{Data gathering instruments}

In this study, the Family Resilience Scale (FRS) was used to determine the resilience levels of parents of patients with T1DM, and COPE Inventory was applied to assess their coping attitudes. We applied the Children's Depression Inventory (CDI) to determine the level of depression in children, and the Screen for Child Anxiety Related Disorders (SCARED) to evaluate anxiety disorders. All participants filled out the personal information form to assess their sociodemographic characteristics and the patient's family. Participants filled out the questionnaires on their own.

Personal Information Form: The form includes questions about sociodemographic features such as the children's ages, gender, number of siblings, education status of the parents, the profession of the parents, family type, income level, the field of work, years diagnosed with T1DM and the average HbA1c levels of the previous year.

Children's Depression Inventory (CDI): In this study, the Children's Depression Inventory developed by Kovacks in 1981, was used to determine the level of depression in children. Öy conducted the validity and reliability study in our country in 1991. It consists of 27 questions evaluating the last two weeks of the child. There are three statements scored as 0,1 , and 2 in each item, and increasing scale scores indicate that the level of depression is high. The highest score that can be obtained from the scale is 54 , and the cut-off point is $19 .{ }^{9}$

Screen for Child Anxiety Related Disorders (SCARED): The Screen for Child Anxiety Related Disorders (SCARED) developed by Birmaher et al. to screen for childhood anxiety disorders has a parent and a child form, 
and Çakmakçı has carried out the Turkish validity and reliability study. ${ }^{10}$ SCARED consists of a total of 41 items. It is accepted that scores of 25 and higher are a warning sign for anxiety. The scale also includes somatization, panic disorder, generalized anxiety disorder, separation anxiety, social phobia, and school fear subscales. In this study, only the child form of the scale was used.

COPE Inventory: The scale developed by Carver and friends is a self-reported scale consisting of 60 questions. Its Turkish validity and reliability study was conducted by Ağargün et al. ${ }^{11}$ The scale consists of 60 questions and 15 subscales including active coping, planning, use of instrumental social support, religious coping, focusing on the problem and venting of emotions, positive re-interpretation, and development, humor, acceptance, use of emotional support, restraint, denial, behavioral disengagement, mental disengagement, suppressing other activities, and substance use. Each subscale is divided into three groups of four questions (problem-focused, emotion-focused, and non-functional). Each of these subscales provides information about a different coping attitude. In conclusion, the level of the scores obtained in the subscales makes it possible to comment on which the person more frequently uses a coping attitude.

Family Resilience Scale (FRS): The Family Resilience Scale (FRS), developed by Kaner and Bayraklı, consists of a total of 34 items and eight subscales, including optimism, bellicosity, self-efficacy, social support, motivation for purpose, openness to innovation, predicting risks and social competence. Obtaining a high score in the FRS indicates that resilience is high (it defines me very well - 5 points, it does not define me at all - 1 point). ${ }^{12}$

Data analysis: Statistical analysis of the data was performed using the IBM SPSS 23.0 (IBM Corp. Released 2015. IBM SPSS Statistics for Windows, Version 23.0. Armonk, NY: IBM Corp.) statistical software bundle. The normality distribution of the data was examined by the Shapiro-Wilk test. Descriptive statistics were expressed as the mean \pm standard deviation or median (minimum-maximum) for the quantitative data and frequency and percentage for the qualitative data. The Spearman correlation coefficient examined the relationships between the variables. The significance level was determined as $\alpha=0,05$.

\section{Results}

In our study, we included seventy-one children diagnosed with T1DM for an average of 3.7 (1-13 years) years. The sample's sociodemographic characteristics in the study have been displayed in the table (Table 1).

A positive statistically significant correlation was found in our study between the duration of diabetes and the HbA1c level ( $r=0.315 ; p=0.007)$. No statistically significant correlation was determined between the total CDI and SCARED scores and the duration of diabetes and $\operatorname{HbA1c}(\mathrm{p}=0.059, \mathrm{p}=0.638$, respectively). 
Table 1. Demographic characteristics of the sample*

\begin{tabular}{|l|c|}
\hline & $\mathbf{n = 7 1}$ \\
\hline Gender (Female) & $38(53.52)$ \\
\hline Age (year) & $13.42 \pm 2.69$ \\
\hline Duration of diabetes (year) & $3.7(1-13)$ \\
\hline HbA1c (\%) & $8.35(5-16)$ \\
\hline Mother's age (year) & $40.66 \pm 6.73$ \\
\hline Father's age (year) & $43.93 \pm 7.70$ \\
\hline Mother education status & \\
Uneducated & $5(7.04)$ \\
Elementary school & $41(57.75)$ \\
Secondary school & $8(11.27)$ \\
College & $17(23.94)$ \\
High school & $0(0.00)$ \\
\hline Father education status & $0(0.00)$ \\
Uneducated & $34(47.88)$ \\
Elementary school & $14(19.72)$ \\
Secondary school & $15(21.13)$ \\
College & $8(11.27)$ \\
High school & \\
Monthly family income & $17(23.94)$ \\
2000 & $38(53.52)$ \\
2000-3000 & $16(22.54)$ \\
\hline 3000 & \\
\hline
\end{tabular}

${ }^{*}$ Descriptive statistics were given as mean \pm standard deviation, median(min-max), or $\mathrm{n}(\%)$.

HbA1c: glycosylated hemoglobin

Table 2. Descriptive statistics of the mothers' and fathers' coping attitudes assessment scale

\begin{tabular}{|l|c|c|c|c|}
\hline & Mean & sd & Minimum & Maximum \\
\hline Mothers' problem-focused coping & 59.20 & 7.02 & 39.00 & 71.00 \\
\hline Mothers' emotion -focused coping & 58.39 & 7.15 & 34.00 & 71.00 \\
\hline Mothers' non-functional-focused coping & 39.54 & 7.08 & 26.00 & 65.00 \\
\hline Fathers' problem-focused coping & 59.95 & 9.37 & 35.00 & 76.00 \\
\hline Fathers' emotion -focused coping & 56.29 & 7.16 & 32.00 & 73.00 \\
\hline Fathers' non-functional-focused coping & 40.14 & 9.53 & 24.00 & 70.00 \\
\hline
\end{tabular}

sd: standard deviation 
Table 3. Correlation analyses between the resilience levels of the mothers-fathers and children's SCARED, SCARED subscales, and CDI

\begin{tabular}{|c|c|c|c|c|c|c|}
\hline \multirow{2}{*}{\multicolumn{2}{|c|}{ Resilience levels }} & \multirow{3}{*}{$\begin{array}{l}\text { CDI } \\
-0.257\end{array}$} & \multirow{3}{*}{$\begin{array}{l}\text { SCARED } \\
-0.116\end{array}$} & \multicolumn{3}{|c|}{ SCARED subscales } \\
\hline & & & & $\begin{array}{l}\text { Somatization/ } \\
\text { panic disorder }\end{array}$ & $\begin{array}{l}\text { Social } \\
\text { phobia }\end{array}$ & $\begin{array}{c}\text { Generalized } \\
\text { anxiety } \\
\text { disorder }\end{array}$ \\
\hline \multirow{2}{*}{ Mothers } & $\mathrm{r}$ & & & -0.149 & -0.141 & -0.087 \\
\hline & $\mathrm{p}$ & 0.035 & 0.358 & 0.231 & 0.250 & 0.489 \\
\hline \multirow{2}{*}{ Fathers } & $r$ & -0.144 & 0.031 & 0.007 & 0.125 & 0.070 \\
\hline & $\mathrm{p}$ & 0.250 & 0.810 & 0.957 & 0.319 & 0.581 \\
\hline
\end{tabular}

CDI: Children's Depression Inventory; SCARED: Screen for Child Anxiety Related Disorders

No significant correlation was determined between mothers' and fathers' resilience levels, ages, education levels, and average HbA1c levels, and diabetes duration. A negative and significant correlation was found between the education level of the mothers and the subscale scores of "denial" and "behavioral disengagement" $((r=-0.375 ; p=0.002),(r=-0.292 ; p=0.014)$, respectively). A negative and significant correlation was found between the duration of diabetes and the mother's "mental disengagement" subscale ( $\mathrm{r}=-0.264 ; \mathrm{p}=0.026)$. Again, a negative and significant correlation was found between the duration of diabetes and the fathers' "active coping," "planning," and the "use of emotional, social support" subscales ((r=-0.302; p=0.014), (r=-0.364; $\mathrm{p}=0.003),(\mathrm{r}=-0.282 ; \mathrm{p}=0.023)$, respectively). When the average scores of the mothers' and fathers' coping attitudes assessment scale were examined, it was found that the scores of the "Problem-Focused Coping" attitude were highest. Both mothers and fathers used the "Problem-Focused Coping" attitude the most and the "Non-functional Coping" attitude the least (Table 2). In our study, a positive statistically significant correlation was found between the mothers' "humor" COPE subscale and the child's CDI ( $r=0.263 ; \mathrm{p}=0.028)$, and the fathers' "active coping" COPE subscale and the child's "SCARED total" scores ( $r=0.339 ; \mathrm{p}=0.006$ ).

A negative and significant correlation was found between the mothers' resilience levels and the children's CDI scores $(r=-0.257 p=0.035)$. No significant relationship was found between the mothers' resilience levels and the children's SCARED and SCARED subscales. Again, no significant correlation was found between the fathers' resilience levels and the CDI, SCARED, and SCARED subscale scores of the children (Table 3). 


\section{Discussion}

In this study in which we aimed to determine how the strategies of coping with stress and resilience among mothers and fathers of children with T1DM affected the depression and anxiety levels and glycemic control of the child, it was observed that the depression scores of the children decreased as the resilience level of the mothers increased. It was noted that both mothers and fathers used the problem-focused coping attitude the most, and the non-functional coping attitude the least. In particular, as the mother's education level decreased, the 'denial' and 'behavioral disengagement" attitudes increased.

Resilience is the individual's positive adaptation and development and survival despite being exposed to situations and experiences that have negative consequences. ${ }^{5}$ The effective coping strategies people use as they encounter difficulties in life make them more resilient. The levels of hope and satisfaction from the life of more resilient people increase. While many studies have assessed families' resilience with chronic diseases, a study evaluating the resilience levels of the parents of patients with T1DM has not yet been conducted. Most studies conducted are studies that assess the resilience levels of patients with diabetes. DeNisco evaluated the relationship between the resilience levels and glycemic control of adult patients with type 2 diabetes, and those with high resilience were found to have better glycemic control levels. ${ }^{7}$ In a study conducted by Yi et al. on patients with diabetes $>18$ years of age, it was observed that those with high resilience had better glycemic control. ${ }^{8}$ In our study, no relation was found between the resilience levels of parents and education, age, duration of diabetes, and glycemic control. However, it was determined that as the mother's resilience level increased, the child's depression score decreased. While fathers play an essential role in diabetes management, mothers are usually the parents responsible for most of the treatment management. ${ }^{13}$ Based on this, it is inevitable that the mother's resilience will positively or negatively affect the child. In a study examining families' resilience with autism and mild to moderate mental retardation, mothers' resilience level explained their levels of hope significantly. ${ }^{14}$ In many studies conducted, it has been found that as the resilience level of families increases, the quality of life increases. ${ }^{15,16} \mathrm{~A}$ positive correlation was found between families' resilience level with autism and their children's sleep quality in another study.17

Strategies to deal with stress are examined in three categories: problem-focused, emotion-focused, and nonfunctional. In the problem-focused coping method, individuals evaluate stressful situations and follow ways to manage or change them. ${ }^{18}$ In our study, it was found that both mothers and fathers mostly used problemfocused coping methods. Similarly, in the study conducted by Shavaki et al., they found that mothers of children with T1DM mostly used problem-focused coping. This was an important factor in stress management. ${ }^{19}$ In another study on parents of a child with autism, they also found that the parents mostly used the problemfocused coping method. ${ }^{20}$ In another study on parents of mentally disabled children, it was found that mothers used the problem solving (active coping) strategy more frequently. ${ }^{21}$ In many studies conducted on children 
with autism, it was found that families made plans based on the problem-focused coping style as a coping method despite having high-stress levels. ${ }^{22-24}$ Researchers have linked the families of a child with autism resorting to more positive coping strategies to the necessity to address the needs that arise due to the nature of autism. Studies conducted with mothers of children diagnosed with epilepsy found that they used nonfunctional and emotion-focused coping more frequently. ${ }^{25}$ Furthermore, in studies examining the mothers of mentally disabled children with delayed development, it was determined that they used emotion-focused coping strategies more often. ${ }^{26,27}$

In a study that evaluated parents' parents' coping attitudes and demographic characteristics, while no relationship was found between the coping attitudes of mothers of a child with T1DM and their education levels, ages, and income levels, in our study, ${ }^{28}$ it was found that the non-functional coping attitudes of "denial" and "behavioral disengagement" increased as the education level of the mothers decreased. In other words, it was observed that the use of functional coping strategies increased as the education level of the mothers increased.

In our study, no relation was found between the coping attitudes of parents and glycemic control. Similar results were found in similar studies conducted. ${ }^{28,29}$

When we compared the children's coping strategies and the anxiety and depression levels, a positive correlation was found between using the problem-focused coping mechanism "active coping" by mothers and having high anxiety levels. The child's perception can explain this situation that the mother is dealing with a problem when the mother uses active coping. In emotion-focused coping, people try to reduce their stress by distancing themselves from their negative emotions. In our study, a positive correlation was found between using the "humor" strategy, which is an emotion-based mechanism by mothers, and high depression levels among children. It is thought that children's depression levels increase when mothers use the humor strategy because children believe that their mother is not sufficiently concerned with their problem. Unlike our study, in a study that examined the coping strategies used by mothers of children with various chronic diseases, particularly oncological diseases, it was determined that functional coping strategies such as planning, positive re-interpretation, and active coping were related to the child having less psychiatric symptoms. ${ }^{30}$ Unlike our study, Jaser, and friends found no association between the mothers' coping strategies and children's depression among the mothers of adolescents with T1DM. ${ }^{28}$ According to these results, we think that the depression and anxiety levels may be reduced or even eliminated by using effective coping strategies by the mother of children with T1DM.

Based on the findings obtained from our study, in particular, the resilience level and coping strategies of the mother affect the psychiatric symptoms (depression, anxiety) of the child. In conclusion, determining the level 
of resilience of families and attempts to increase the level of resilience can increase the adaptation of families and help reduce the psychological distress in children. Besides, the use of adequate coping strategies by mothers and fathers also increases the family's disease compliance and may reduce the psychological distress of children. For this reason, the families of children with T1DM should continuously be trained to develop effective coping strategies under the supervision of specialist health professionals.

Our study's limitations are the small sample size, the patients, and parents participating in the study being from a single center and filling the questionnaires themselves. 


\section{References}

1. Tuomilehto J. The emerging global epidemic of type 1 diabetes. Curr Diab Rep 2013 Dec;13(6):795804.

2. American Diabetes Association. Standards of medical care in diabetes. Diabetes Care 2012;35:S11S63.

3. Ganjvar M, Jafarimanesh H, Jadid Milani M, Sadeghi H. The strategies to deal with stress in mothers of children with type I diabetes. IJPN 2015;3(2):51-61.

4. Patterson J, Blum RW. Risk and resilience among children and youth with disabilities. Arch Pediatr Adolesc Med 1996;150:692-98.

5. Masten AS, Cutuli JJ, Herbers JE, Reed MGJ. Resilience in development. In C. R. Snyder and S. J. Lopez (Eds.), Handbook of positive psychology (pp. 74-88). New York, 2002, NY: Oxford University Press.

6. Batty KE, Fain JA. Factors Affecting Resilience in Families of Adults With Diabetes. Diabetes Educ 2016 Jun;42(3):291-8.

7. DeNisco S. Exploring the relationship between resilience and diabetes outcomes in African Americans. J Am Assoc Nurse Pract 2011;23:602-10.

8. Yi JP, Vitallano PP, Smith RE, Yi JC, Weinger K. The role of resilience on psychological adjustment and physical health in patients with diabetes. Br J Health Psychol 2008;13:311-25.

9. ̈y B. Çocuklar İçin Depresyon Ölçeği: Geçerlik ve Güvenirlik Çalışması. Türk Psikiyatri Dergisi 1991;2:132-6.

10. Çakmakçı F. Çocuklarda Anksiyete Bozukluklarını Tarama Ölçeği Geçerlik Ve Güvenirlik Çalışması. Tıpta Uzmanlık Tezi, Kocaeli Üniversitesi Tıp Fakültesi, Kocaeli; 2004.

11. Ağargün MY, Beşiroğlu L, Kıran ÜK, Özer ÖA, Kara H. COPE (Başa çıkma tutumlarını değerlendirme ölçeği): Psikometrik özelliklere ilişkin bir ön çalışma. Anadolu Psikiyatr Derg 2005;6:221-6.

12. Kaner S, Bayraklı H. Aile Yılmazlık Ölçeği: Geliştirilmesi, geçerlik ve güvenirliği. Ankara Üniversitesi Eğitim Bilimleri Fakültesi Özel Eğitim Dergisi 2010;11 (2):47-62.

13. Kovacs $\mathrm{M}$, Iyengar $\mathrm{S}$, Goldston $\mathrm{D}$, et al. Psychological functioning among mothers of children with insulin-dependent diabetes mellitus: A longitudinal study. Journal of Consulting and Clinical Psychology 1990;58:189-95.

14. İşcan GÇ, Malkoç A. Özel gerkesinimli çocuğa sahip ailelerin umut düzeylerinin başa çıkma yeterliliği ve yılmazlık açısından incelenmesi. Trakya Üniversitesi Eğitim Fakültesi Dergisi 2017;7(1):120-7.

15. Demiray G. Özel gereksinimli çocuğu olan ailelerde yaşam kalitesi, umutsuzluk ve yılmazlık arasındaki ilişkilerin incelenmesi. Yüksek Lisans Tezi, Marmara Üniversitesi, Psikolojik Danışmanlık ve Rehberlik, İstanbul;2019. 
16. Karimirad MR, Seyedfatemi N, Noghani F, Dehkordi AH, Barasteh S. The relationship between resilience and quality of life in family caregivers of patients with mental disorders. J Clin Diagn Res 2018;12(11):5-8

17. Roberts CA, Hunter J, Cheng AL. Resilience in Families of Children With Autism and Sleep Problems Using Mixed Methods. J Pediatr Nurs 2017;37:e2-e9.

18. Glanz K, Rimer BK, Viswanath K. Health behavior and health education: theory, research, and practice: Wiley; 2008.

19. Shavaki MA, Harandi TF, Pourabbasi A, Rahimzadeh M. Coping strategies in Iranian mothers of children with type 1 diabetes. J Diabetes Metab Disord 2018;17(2):137-42.

20. Salas BL, Rodríguez VY, Urbieta CT, Cuadrado E. The role of coping strategies and self-efficacy as predictors of life satisfaction in a sample of parents of children with autism spectrum disorder. Psicothema 2017;29(1):55-60.

21. Keskin, G. Bilge, A. Engin, E. Dülgerler S. Zihinsel engelli çocuğu olan anne-babaların kaygl, anne-baba tutumları ve başa çıkma stratejileri açısından değerlendirilmesi. Anadolu Psikiyatri Dergisi 2010;11(1):30-7.

22. Pepperell TA, Paynter J, Gilmore L. Social support and coping strategies of parents raising a child with autism spectrum disorder. Early Child Dev Care 2018;188(10):1392-404.

23. Cuzzocrea F, Murdaca AM, Costa S, Filippello P, Larcan R. Parental stress, coping strategies and social support in families of children with a disability. Child Care Pract 2016;22(1):3-19.

24. Wang P, Michaels CA, Day MS. Stresses and coping strategies of Chinese families with children with autism and other developmental disabilities. J Autism Dev Disord 2011;41:783-95.

25. Başkale H, Çetinkaya B, Ceylan SS, Öztaş Ü. Epilepsili çocukların annelerinin yaşam doyumu ve başa çıkma tutumları. Güncel Pediatr 2019;17(2):265-78.

26. Şengül S, Baykan H. Zihinsel engelli çocukların annelerinde depresyon, anksiyete ve stresle başa çıkma tutumları. Kocatepe Tıp Dergisi 2013;14:30-9.

27. Glidden LM, Billings FJ, Jobe BM. Personality, coping style and well-being of parents rearing children with developmental disabilities. J Intellect Disabil Res 2006;50(12):949-62.

28. Jaser SS, Linsky R, Grey M. Coping and psychological distress in mothers of adolescents with type 1 diabetes. Matern Child Health J 2014;18:101-8.

29. Stallwood L. Influence of caregiver stress and coping on glycemic control of young children with diabetes. J Pediatr Heal Care 2005;19(5):293-300.

30. Çöp E, Dinç GŞ, Kültür SEÇ. Kronik Hastalığı Olan Çocukların Annelerinde Baş Etme Becerilerinin Psikiyatrik Belirtiler ile İlişkisi: Bir Ön Çalıșma. Türkiye Çocuk Hastalıkları Dergisi 2016;10(3):170-6. 